UDC 539.3

\title{
EFFECT OF HEATING ON THE NATURAL VIBRATIONS OF THIN PARABOLIC SHELLS
}

\author{
V.A. Bazhenov, \\ Doctor of Technical Science \\ O.P. Krivenko, \\ Candidate of Science (Engineering) \\ Yu.V. Vorona, \\ Candidate of Science (Engineering) \\ Kyiv National University of Construction and Architecture \\ 31, Povitroflotsky ave., Kyiv, Ukraine, 03680
}

The modal analysis of parabolic shells of revolution exposed to temperature field is carried out. The analysis is performed according to the method, which is based on the relations of the threedimensional theory of thermoelasticity, a finite-element formulation of the problem in increments and uses the finite element moment scheme. A universal finite element is used to model a thin elastic shell. The finite element is based on an isoparametric solid finite element with polylinear shape functions for coordinate and displacement interpolation. Evaluation of the effect of the temperature field on the parameters of the natural vibrations of the shell is performed according to the developed method in two stages. The new stress-strain state of the structure, caused by the applied temperature field, is determined using a geometrically non-linear approach. Further, the frequencies and modes of the natural vibrations of the shell whose shape is perturbed by the action of the temperature field are calculated. The effect of uniform and non-uniform heating on the natural vibrations of parabolic shells of revolution with various heights is investigated. The vibrations of the parabolic shells modelling rocket fairings are studied. The phenomenon of aerodynamic heating of a parabolic shell (head fairing) may occur at the initial stage of entry of the carrier rocket into the atmosphere. This can lead to significant heating of the fairing surface. At the same time the shell is non-uniformly heated through the height. The considered parabolic shells are essentially deep and rather rigid. Therefore, the effect of heating on the characteristics of natural vibrations is insignificant. It has been found that shallow shells have lower frequencies and significantly different modes of natural vibration. Presented studies have shown the effectiveness of the application of the developed approach to the modal analysis of the shells.

Keywords: vibrations, temperature filed, parabolic shell, universal solid finite element.

\section{Introduction}

Elements of shell structures can be exposed to significant external thermal fields under real operating conditions. The presence of heating can significantly affect the dynamic characteristics of the structure. This in turn can lead to an emergency. Taking into account the action of the temperature field makes it possible to increase the reliability of determining the stress-strain state and vibrations of shell systems during their operation. This question has been insufficiently studied due to the increased complexity of such problems [1-5]. Therefore, it seems important to assess the effect of heating on the natural vibrations of thin elastic shells.

The present study is a continuation of our previous paper [6]. Modal analysis of thin parabolic shells of constant thickness, which are under the action of a temperature field, is considered. The application area of parabolic shells is

(C) Bazhenov V.A., Krivenko O.P., Vorona Yu.V. 
rather wide in various branches of engineering and in construction [7-9]. The most widely used constructions such as parabolic domes can be found in structural systems such as aerospace and underwater vehicles $[7,8,10,11]$. Despite this, a relatively small number of works are devoted to their study $[6,7,10-15]$.

Modal analysis is performed according to the method [1]. The technique is based on the relations of the three-dimensional theory of thermoelasticity, the finite element formulation of the problem in increments, and the use of the moment finite element scheme [16,17]. Evaluation of the effect of the temperature field on the parameters of the shell natural vibrations is carried out in accordance with the developed technique in two stages. The new stress-strain state of the structure due to the applied temperature load (temperature field) is determined by a geometrically nonlinear method $[16,17]$. Next, the frequencies and modes of natural vibrations of the shell which shape is disturbed by the action of the temperature field are calculated.

\section{Statement of the problem}

Shell structures may be under the action of different temperature loads (fields) during the operation. Such various thermomechanical conditions may occur in building, airframe, space, and other structures because of a change in the environmental conditions, a difference between the heating rates of massive ribs and thin casing of the aircraft, etc. The phenomenon of aerodynamic heating of a parabolic shell (head fairing) can occur, for example, at the initial stage of entry of the rocket fairing into the atmosphere [8]. At this stage of the flight, the air is dense enough and there is a strong heating of the fairing surface. A possible temperature distribution over the surface of the head fairing is shown in Fig. 1 (the figure is taken as an example from [8]). At the same time, room temperature $20^{\circ} \mathrm{C}$ is maintained inside the enclosure compartment.

The effect of uniform and non-uniform heating on the natural vibrations of parabolic shells of revolution with various heights is investigated. The vibrations of the parabolic shells modelling rocket fairings are studied. We consider paraboloids of constant thickness $h$, height $H$ and radius of the support contour $R$. The shape of the middle surface of the shell in the Cartesian coordinate system $x^{i^{\prime}}$ is given by the equation (Fig. 2):

$$
x^{1^{\prime}}=H\left[1-\frac{\left(x^{2^{\prime}}\right)^{2}+\left(x^{3^{\prime}}\right)^{2}}{R^{2}}\right] .
$$

The shell is clamped at the edges and the material is isotropic $(E, v$, and $\alpha$ are the elastic modulus, Poisson's ratio, and linear expansion coefficient of the nonheated shell). According to [7], the input data are: $E=7.2 \cdot 10^{4} \mathrm{MPa}$, $v=0.3, \alpha=0.25 \cdot 10^{-4} \mathrm{deg}^{-1} ; R=2 \mathrm{~m}, h=5 \mathrm{~mm}$. Three cases of the height are examined $(H=1,2$, and $4 \mathrm{~m}$.). In [6], a study of the convergence and accuracy of solutions for these shells in the absence of heating have been made. Results were compared with the data from [7] and with the data obtained using the SCAD program for finite element structural analysis [18]. The finite element shell model was a half of the panel with uniform mesh along radius and 
circumference. The solutions converged on $40 \times 50 \mathrm{FE}$ mesh. Analysis has shown that the adopted design scheme excludes multiple eigenfrequencies from consideration. However, this does not interfere with the analysis of the natural vibrations of the structure, considering only single eigenfrequencies and the corresponding forms of vibrations. In general, the problem of determining the eigenfrequencies and vibration modes of the shell, which are one of the main dynamic characteristics of any elastic system, occupies an important place in the study of the behavior of any structure.

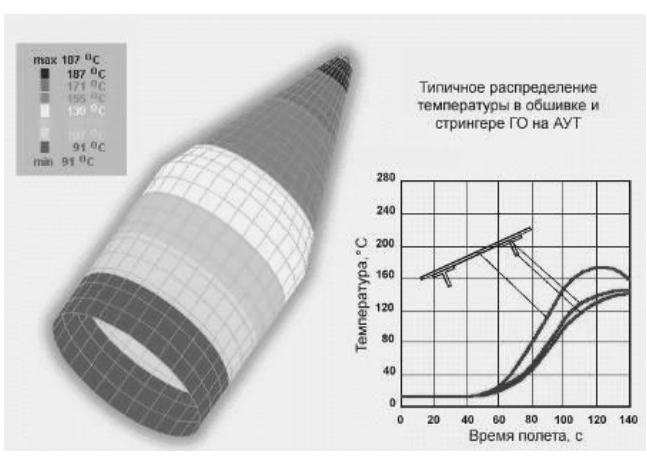

Fig. 1. An example of a temperature distribution in a fairing [8]

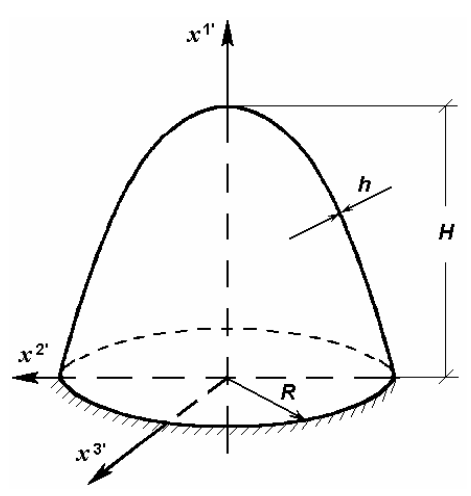

Fig. 2. Parabolic shell of revolution

Three variants of the distribution of the temperature field in the shell are considered: (i) uniform heating throughout the shell volume, (ii) uniform heating throughout the thickness and non-uniform throughout the height, (iii) non-uniform heating throughout the thickness and the height.

\section{Analysis of natural vibrations of parabolic shells that are in a temperature field}

2.1. Uniform heating all over volume of the shell. The effect of heating on the vibration of paraboloids of various heights $(H=1,2$, and $4 \mathrm{~m})$ is examined for four cases of uniform temperature increment by $T^{\circ} \mathrm{C}=0,50,150,165$.

For paraboloids with a height of $H=1$ and $2 \mathrm{~m}$, an increase in frequencies $\omega_{i}$ is observed with an increase in the temperature increment $T$. We have the opposite effect for deeper shells $(4 \mathrm{~m})$, where frequencies $\omega_{i}$ decrease with increasing temperature. In all cases, uniform heating of the shells practically does not affect the values of natural frequencies. Moreover, the frequency spectrum in all cases is quite dense. Noticeable vibrations occur in the middle part of the shell closer to the clamped edge with forming waves in the circumferential direction (Fig. 3). There is no wave formation at the pole of the shell.

For the shell with a height $H=1 \mathrm{~m}$ (Fig. 4), heating at $T=50^{\circ} \mathrm{C}$ is accompanied by a small increase in frequency (only 3\%) (Table 1) and has little effect on the nature of the lower vibration modes. Heating at $T=150^{\circ} \mathrm{C}$ and above leads to an increase in frequencies (up to $5 \%$ ) and causes the same changes in the respective modes. 

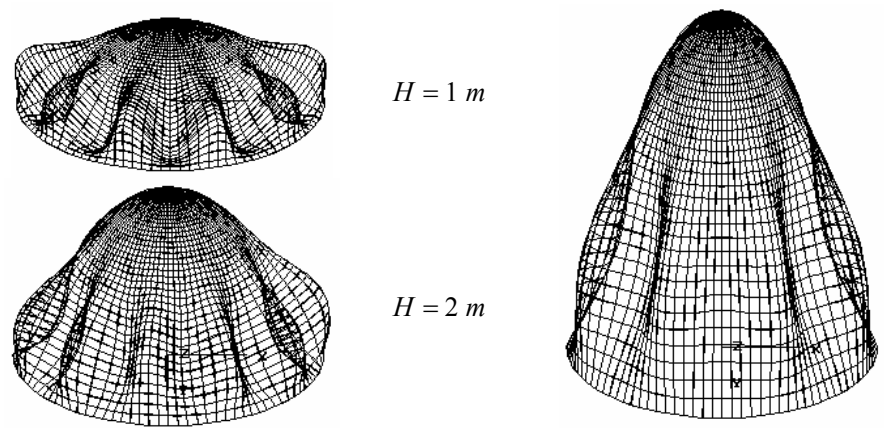

$H=4 m$

Fig. 3. Natural modes of shells with different heights $\left(T=0^{\circ} \mathrm{C}\right)$

Table 1

\begin{tabular}{|c|r|r|r|r|r|}
\hline \multirow{2}{*}{$+\omega_{\mathrm{T}}^{\mathrm{T}} T^{\circ} \mathrm{C}$} & \multicolumn{5}{|c|}{$\omega_{1}, H z(H=1 \mathrm{~m})$} \\
\cline { 2 - 6 } & $\omega_{1}$ & $\omega_{2}$ & $\omega_{3}$ & $\omega_{4}$ & $\omega_{5}$ \\
\hline $0^{\circ}$ & 230.40 & 230.82 & 231.45 & 232.74 & 233.96 \\
\hline $50^{\circ}$ & 237.08 & 237.41 & 238.18 & 239.20 & 240.81 \\
\hline $150^{\circ}$ & 242.42 & 242.71 & 243.55 & 244.49 & 246.08 \\
\hline $165^{\circ}$ & 241.90 & 242.18 & 243.03 & 243.96 & 245.57 \\
\hline \hline$\Delta_{0^{\circ}}^{165^{\circ}}, \%$ & 5.00 & 4.92 & 5.00 & 4.82 & 4.96 \\
\hline
\end{tabular}

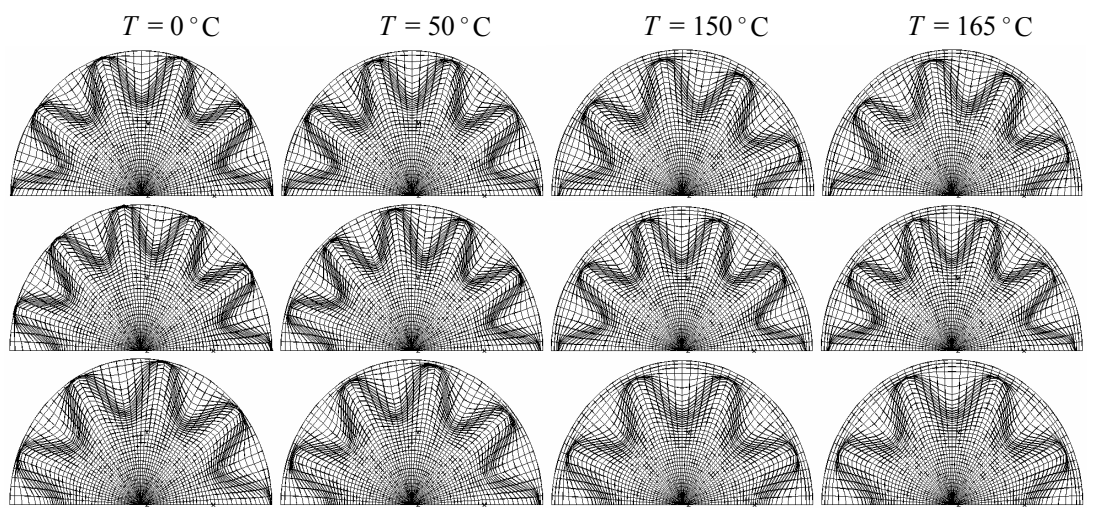

Fig. 4. The first three modes of vibrations for the shell $(H=1 \mathrm{~m})$ uniformly heated

The insignificant effect of heating on frequency values can be explained as follows. Heating gives the shell a new shape (Fig. 5) and only slightly increases the paraboloid's height by $0.39,1.14$ and $1.24 \mathrm{~cm}$, respectively. For clarity forms are presented on a significantly distorted scale. 

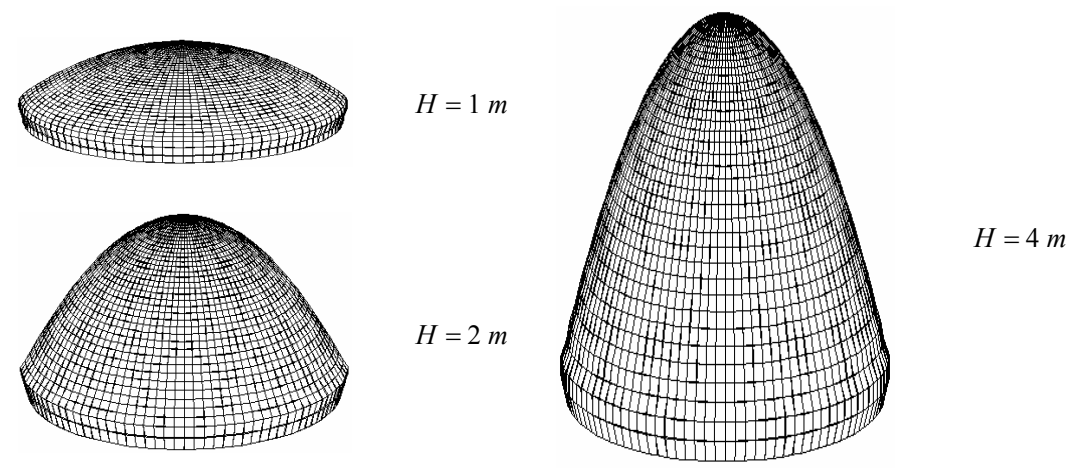

Fig. 5. The shape of the parabolic shell of various heights after uniform heating

For the shell with a height $H=2 \mathrm{~m}$, heating by $T=50^{\circ} \mathrm{C}$ or more leads to a slight increase in the vibration frequencies (up to 3\%, Table 2) and the same restructuring of the modes (Fig. 6). As above, this can be explained by the change in the parabolic shape of the shell to a drop-like shape with a relatively smaller increase in height (than in the first variant) by $0.195,0.575,0.63 \%$.

Table 2

\begin{tabular}{|c|r|r|r|r|r|}
\hline \multirow{2}{*}{$+{ }_{\mathrm{T}}^{\top} T^{\circ} \mathrm{C}$} & \multicolumn{5}{|c|}{$\omega_{i}, H z(H=2 m)$} \\
\cline { 2 - 6 } & $\omega_{1}$ & \multicolumn{1}{|c|}{$\omega_{2}$} & $\omega_{3}$ & \multicolumn{1}{c|}{$\omega_{4}$} & \multicolumn{1}{c|}{$\omega_{5}$} \\
\hline $0^{\circ}$ & 162.57 & 162.69 & 164.48 & 164.83 & 168.47 \\
\hline $50^{\circ}$ & 164.19 & 164.26 & 166.11 & 166.42 & 170.17 \\
\hline $150^{\circ}$ & 167.19 & 167.61 & 168.77 & 170.07 & 172.47 \\
\hline $165^{\circ}$ & 167.61 & 168.07 & 169.14 & 170.57 & 172.81 \\
\hline \hline$\Delta_{0^{\circ}}^{165^{\circ}}, \%$ & 3.10 & 3.31 & 2.83 & 3.48 & 2.58 \\
\hline
\end{tabular}

$T=0{ }^{\circ} \mathrm{C}$
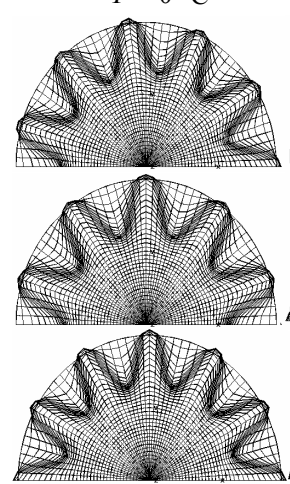
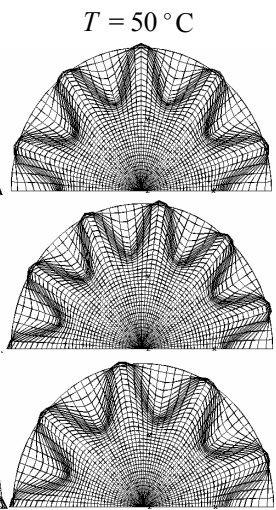

$T=150{ }^{\circ} \mathrm{C}$
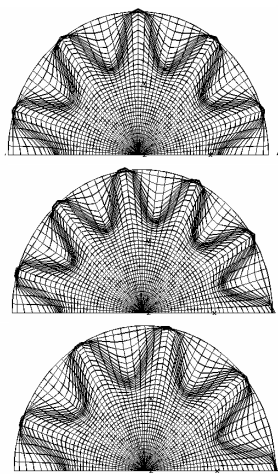

$T=165^{\circ} \mathrm{C}$
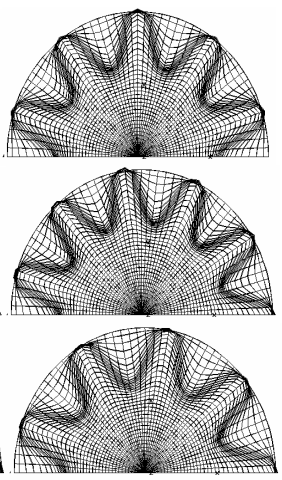

Fig. 6. The first three modes of vibrations for the shell $(H=2 \mathrm{~m})$ uniformly heated 
For the shell with a height $H=4 \mathrm{~m}$, heating at $T=165^{\circ} \mathrm{C}$ has practically no effect on frequencies that decrease by less than $1 \%$ (Table 3 ) and does not affect the modes (Fig. 7). The corresponding modes are of the same type for an unheated and heated shell (for all considered temperature values). The relative increment of the shell height due to heating is less than $0.5 \%$, and the shape differs insignificantly from the initial one.

Table 3

\begin{tabular}{|c|r|r|r|r|r|}
\hline \multirow{2}{*}{$+T_{\mathrm{T}}^{\mathrm{T}} T^{\circ} \mathrm{C}$} & \multicolumn{5}{|c|}{$\omega_{i}, H z(H=4 \mathrm{~m})$} \\
\cline { 2 - 6 } & $\omega_{1}$ & $\omega_{2}$ & $\omega_{3}$ & $\omega_{4}$ & $\omega_{5}$ \\
\hline $0^{\circ}$ & 77.832 & 78.303 & 79.887 & 81.062 & 84.836 \\
\hline $50^{\circ}$ & 77.482 & 78.002 & 79.491 & 80.849 & 84.414 \\
\hline $150^{\circ}$ & 77.167 & 77.816 & 79.073 & 80.795 & 83.914 \\
\hline $165^{\circ}$ & 77.250 & 77.930 & 79.094 & 80.959 & 83.865 \\
\hline \hline$\Delta_{0^{\circ}}^{165^{\circ}}, \%$ & -0.75 & -0.48 & -0.99 & -0.13 & -1.14 \\
\hline
\end{tabular}
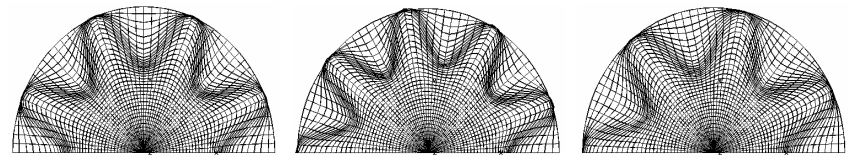

Fig. 7. The first three vibration modes for uniformly heated shell ( $H=4 \mathrm{~m}$ )

2.2. Heating of the shell uniformly throughout the thickness and nonuniformly throughout the height. We study heating of the shell which is uniform throughout the thickness and stepwise throughout the height. Let us consider four sections of a paraboloid with stepwise heating by $T_{i}^{\circ} \mathrm{C}$ along the axis $x^{1^{\prime}}$. It is assumed that the reference shell temperature is $20^{\circ} \mathrm{C}$. In accordance with [8], such temperature increments: $T_{1}=110, T_{2}=135^{\circ} \mathrm{C}$, $T_{3}=150^{\circ} \mathrm{C}$, and $T_{4}=165^{\circ} \mathrm{C}$ are corresponded the following sections of the shell with the height $\frac{3}{20} H, \frac{5}{20} H, \frac{9}{20} H$, and $\frac{3}{20} H$. The first section is near clamped edges.

The effect of the stepwise distribution of temperature on the natural frequencies of the shells is examined for parabolic shells of revolution with the height 2 and $4 m$ (Table 4). As expected, the effect of heating on the values $\omega_{i}$ is insignificant. This can be explained by the fact that the non-uniform temperature distribution has slight effect on the new shell shape after heating (Fig. 8 (a), Fig. 9 (a)). New shell shapes are similar to ones of uniformly heated shells (Fig. 5). 


\begin{tabular}{|c|r|r|r|r|r|}
\hline \multirow{2}{*}{$\Delta, \%$} & \multicolumn{5}{|c|}{$+_{\mathrm{T}}^{\top} \omega_{i}, H z$} \\
\cline { 2 - 6 } & \multicolumn{1}{|c|}{$\omega_{1}$} & \multicolumn{1}{c|}{$\omega_{2}$} & \multicolumn{1}{c|}{$\omega_{3}$} & \multicolumn{1}{c|}{$\omega_{4}$} & \multicolumn{1}{c|}{$\omega_{5}$} \\
\hline \hline$H=2 m$ & 167.46 & 167.67 & 169.25 & 169.85 & 173.11 \\
\hline$\Delta\left(T_{i}^{\circ} / 0^{\circ}\right)$ & 3.01 & 3.06 & 2.90 & 3.05 & 2.75 \\
\hline$\Delta\left(T_{i}^{\circ} / 165^{\circ}\right)$ & -0.09 & -0.24 & 0.06 & -0.42 & 0.17 \\
\hline \hline$H=4 m$ & 77.795 & 78.307 & 79.737 & 81.078 & 84.566 \\
\hline$\Delta\left(T_{i}^{\circ} / 0^{\circ}\right)$ & -0.05 & 0.005 & 0.008 & 0.02 & -0.32 \\
\hline$\Delta\left(T_{i}^{\circ} / 165^{\circ}\right)$ & 0.70 & 0.48 & 0.81 & 0.15 & 0.84 \\
\hline \hline
\end{tabular}

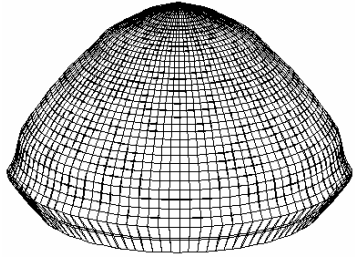

(a)

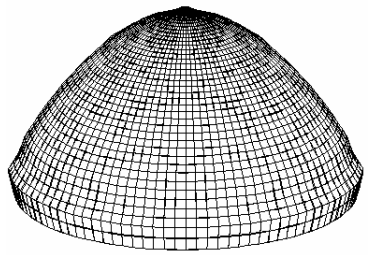

(b)

Fig. 8. Shell shapes ( $H=2, m)$ after stepwise heating throughout the height: (a) uniform heating throughout the thickness, (b) linear heating throughout the thickness

The uniform heating of the paraboloid with a height $H=2 \mathrm{~m}$ increases the value of the lower five natural frequencies only by $3 \%$ compared with an unheated shell $\left(T=0^{\circ} \mathrm{C}\right)$. Compared with a uniformly heated shell at $T=165^{\circ} \mathrm{C}$, this effect is practically absent and amounts to only $1 \%$.

Taking into account the non-uniform heating for a paraboloid with a height $H=4 \mathrm{~m}$ practically does not affect the value of the lower five natural frequencies and is less than $1 \%$ compared with an unheated $\left(T=0^{\circ} \mathrm{C}\right)$ and uniformly heated $\left(T=165^{\circ} \mathrm{C}\right)$ shell.

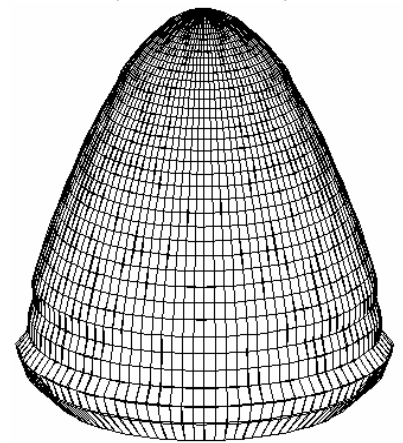

(a)

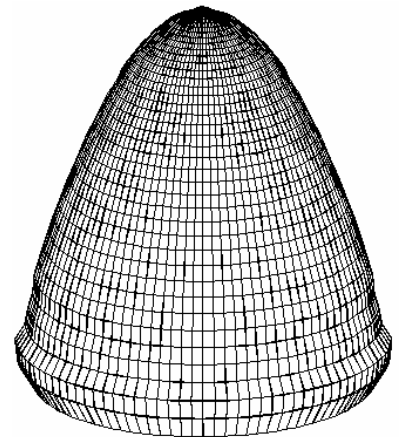

(b)

Fig. 9. Shell shapes ( $H=4, m)$ after stepwise heating throughout the height: (a) uniform heating throughout the thickness, (b) linear heating throughout the thickness 
2.3. Non-uniform heating of the shell. We examine shells which are nonuniformly heated both throughout the height and the thickness ( $H=2$ and $4 \mathrm{~m}$ ). We accept that the law of stepwise temperature change throughout the height is the same as in the previous study. The temperature distribution over the shell thickness is assumed to be linear by the method $[16,17]$. When the upper fiber is heated $\left(T_{i}^{\circ} \mathrm{C}\right)$, the lower fiber remains cold $\left(T=0^{\circ} \mathrm{C}\right)$.

Table 5

\begin{tabular}{|c|c|c|c|c|c|}
\hline \multirow{2}{*}{$\Delta, \%$} & \multicolumn{5}{|c|}{$\overbrace{}^{\top} \omega_{i}, H z$} \\
\cline { 2 - 6 } & $\omega_{1}$ & $\omega_{2}$ & $\omega_{3}$ & $\omega_{4}$ & $\omega_{5}$ \\
\hline \hline$H=2 m$ & 164.98 & 164.99 & 166.94 & 166.98 & 170.98 \\
\hline$\Delta\left(T_{i}^{\circ} / 0^{\circ}\right)$ & 1.48 & 1.41 & 1.50 & 1.30 & 1.49 \\
\hline$\Delta\left(T_{i}^{\circ} / 165^{\circ}\right)$ & -1.57 & -1.83 & -1.30 & -2.10 & -1.06 \\
\hline \hline$H=4 m$ & 77.729 & 78.201 & 79.735 & 80.967 & 84.632 \\
\hline$\Delta\left(T_{i}^{\circ} / 0^{\circ}\right)$ & -0.13 & -0.13 & -0.19 & -0.12 & -0.24 \\
\hline$\Delta\left(T_{i}^{\circ} / 165^{\circ}\right)$ & 0.62 & 0.35 & 0.81 & 0.01 & 0.91 \\
\hline \hline
\end{tabular}

As above, the effect of non-uniform heating on frequency values $\omega_{i}$ is insignificant (Table 5). Non-unifirm heating increases the frequency of the shell for the case $H=2 \mathrm{~m}$ by $1.57 \%$ and for the case $H=4 \mathrm{~m}$ less than $1 \%$. This can also be explained by the fact that the non-uniform temperature distribution has little effect on the new shell shape after heating (Fig. 8 (b), Fig. 9 (b)).

Note that non-uniform heating of paraboloids (paragraphs 2.2 and 2.3) has no result (does not affect) on the type of the lowest modes compared with ones for uniform heating (paragraph 2.1). The parabolic shells considered above belong to the class of deep shells and are rather stiffness. Therefore, temperature effect on the vibration characteristics of deep shells is negligible. But researches have shown the effectiveness of applying the developed approach to the study of modal characteristics of shells.

\section{The effect of the height reduction of the heated parabolic shell on natural vibrations.}

Consider an axisymmetric shallow parabolic panel. The height of shell is 10 times less than of those studied above: $H=0.2 \mathrm{~m}$. The rise of this thin panel is much smaller than the radius of the support boundary. Therefore, this shell can be attributed to the class of shallow ones, since it is generally accepted that for shallow shells $H<R / 5$ [19]. The effect of heating on $T=50^{\circ} \mathrm{C}$ on the modal characteristics of the shallow parabolic panel is analyzed. Two cases are considered: uniform and non-uniform heating throughout the thickness. Heating throughout the height is taken uniform. 
The shell shape after heating (Fig. 10) differs from the corresponding shape of the paraboloid with greater height (Fig. 5). For clarity, the deformed shape is presented on an enlarged scale.

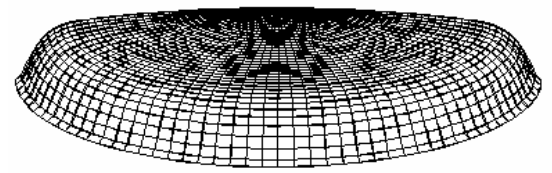

Fig. 10. The shape of a heated parabolic shell $(H=0.2 \mathrm{~m})$

The modal characteristics of the panel before and after heating are presented in Fig. 11 and in Table 6.

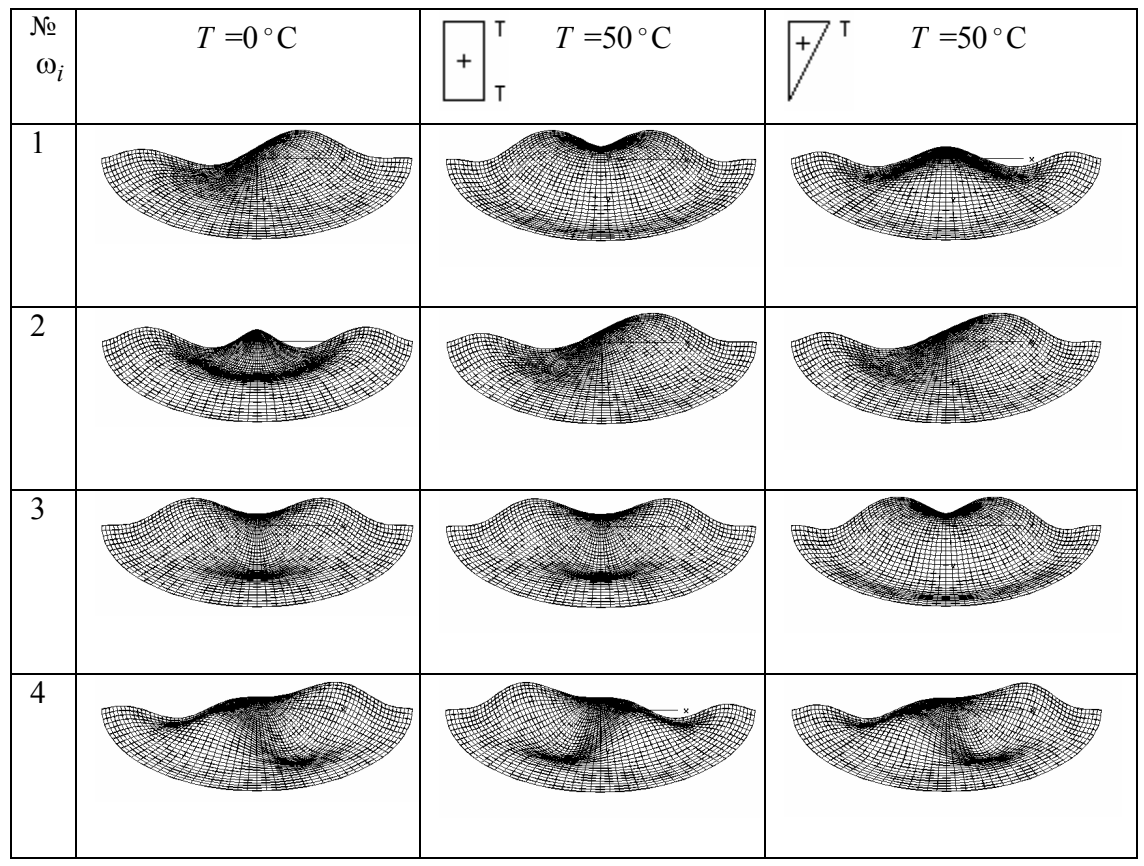

Fig. 11. Vibration modes of a shallow parabolic shell $(H=0.2 \mathrm{~m})$

Table 6

\begin{tabular}{|rc|r|r|r|r|r|}
\hline Case of & heating & $\omega_{1}, \mathrm{~Hz}$ & $\omega_{2}, \mathrm{~Hz}$ & $\omega_{3}, \mathrm{~Hz}$ & $\omega_{4}, \mathrm{~Hz}$ & $\omega_{5}, \mathrm{~Hz}$ \\
\hline $\mathrm{H}_{\mathrm{T}}^{\mathrm{T}}$ & $T=0^{\circ} \mathrm{C}$ & 83.403 & 83.976 & 84.333 & 85.173 & 86.360 \\
\hline & $T=50^{\circ} \mathrm{C}$ & 81.795 & 82.146 & 83.227 & 84.959 & 87.069 \\
\hline${ }^{T^{T^{\circ}}}, \%$ & -1.9 & -2.2 & -1.3 & -0.3 & 0.8 \\
\hline${ }^{\top}$ & $T=50^{\circ} \mathrm{C}$ & 83.118 & 83.322 & 83.518 & 84.036 & 86.010 \\
\hline$\Delta_{0^{\circ}}^{T^{\circ}}, \%$ & -0.3 & -0.9 & -1.0 & -1.3 & -0.4 \\
\hline
\end{tabular}


The frequency spectrum remains fairly dense. The effect of heating on the frequencies is negligible. The difference in their values does not exceed $2.2 \%$ (Table 6).

The types of the vibration modes differ substantially from ones for deeper paraboloids (Fig. 11). In this case, both uniform and non-uniform heating of the shell has a significant effect on the first modes of natural vibrations.

\section{Conclusions}

We have carried out the modal analysis of parabolic shells of revolution exposed to temperature field. The analysis is performed according to the method basing on the relations of the three-dimensional theory of thermoelasticity, a finite-element formulation of the problem in increments and uses the finite element moment scheme. A universal finite element is used to model a thin elastic shell.

The effect of uniform and non-uniform heating on the natural vibrations of parabolic shells of revolution with various heights (deep shells) is investigated. The vibrations of the parabolic shells modelling rocket fairings are studied. The phenomenon of aerodynamic heating of a parabolic shell (head fairing) can occur, for example, at the initial stage of entry of the rocket fairing into the atmosphere. This can cause non-uniform heating along the height of the fairing surface.

Analysis of the calculation results allowed us to make the following conclusions.

Heating of the deep shells has negligible effect on the frequencies of natural vibrations, the spectrum of which is quite dense. The natural vibration frequencies decrease with successive increasing up the height of the paraboloid. At the same time, effect of heating on the first modes of the shell vibrations is observed. Noticeable vibrations occur in the middle part of the shell closer to the clamped edge with forming waves in the circumferential direction. There is no wave formation at the pole of the shell. The effect of heating on the vibration modes decreases with increasing up the height of the shell, and effect from heating completely disappears for shells with $H=4 \mathrm{~m}$.

A decrease in the height of the paraboloid to $H=0.2 \mathrm{~m}$ (a shallow panel) leads to a significant decrease in frequencies and a qualitatively different character of the modes of natural vibrations.

We have shown the effectiveness of applying the developed approach to studying the modal characteristics of shells in a temperature field.

\section{REFERENCES}

1. Bazhenov $V$., Krivenko $O$. Buckling and Natural Vibrations of Thin Elastic Inhomogeneous Shells. - LAP LAMBERT Academic Publishing. Saarbruken, Deutscland, 2018. - 97 p.

2. Krivenko O.P. Vplyv nahrivu na stiykist' i vlasni kolyvannya sferychnoyi paneli pry zmini umov kombinovanoho zakriplennya konturu // Opir materialiv i teoriya sporud: nauk.-tekh. zbirn. - K.: KNUBA, 2015. - Vyp. 96-S. 48-65. [The effect of heating on the stability and natural vibrations of a spherical panel with the changing combined fixation of the boundary // Strength of Materials and Theory of Structures: Scientific-and-technical collected articles. K.: KNUCA, 2015. - Issue 96. - Pp. 48-65. - in Ukrainian].

3. Krivenko O.P. Vplyv poperednoho nahrivu ta zminy umov kombinovanoho zakriplennia konturu na stiikist i vlasni kolyvannia polohykh panelei pry dii tysku // Opir materialiv i 
teoriya sporud: nauk.-tekh. zbirn. - K.: KNUBA, 2016. - Vyp. 97. - S. 107-120. [The effect of preliminary heating and combined fixation of the boundary on the stability and natural vibrations of panels under action of pressure // Strength of Materials and Theory of Structures: Scientific-and-technical collected articles - Kyiv: KNUBS, 2016. - Issue 97. - Pp. 97-110. in Ukrainian].

4. Flyachok V.M., Shvets R.N. Vliyaniye neravnomernogo nagreva na sobstvennyye kolebaniya anizotropnykh tsilindricheskikh obolochek // Teplovyye napryazheniya V elementakh konstruktsiy. 1981. - Vyp. 9. - S. 48-53. [The effect of non-uniform heating on the natural vibrations of anisotropic cylindrical shells // Thermal stresses in structural elements, 1981. Issue. 9. - S. 48-53. - in Russian].

5. Bykov Yu.A., Gnesin V.I. Vliyaniye temperaturnoy neravnomernosti na aerotermouprugiye kolebaniya turbinnoy lopatki // Tekhnologii konstruktsionnykh materialov i mashinostroyeniya. 2011. - S. 39-44. [The effect of temperature non-uniformity on aerothermoelastic vibrations of a turbine blade // Technology of construction materials and mechanical engineering, 2011. - P. 39-44. - in Russian]

6. Bazhenov V.A., Krivenko O.P., Vorona Yu.V. Analiz vlasnykh kolyvan tonkykh parabolichnykh obolonok // Opir materialiv i teoriya sporud: nauk.-tekh. zbirn. - K.: KNUBA, 2019. - Vyp. 102. - S. 171-179. [Analysis of non-state reaction of elastic shell to impulse load // Strength of Materials and Theory of Structures: Scientific-and-technical collected articles Kyiv: KNUBS, 2019. - Issue 102. - Pp. 171-179. - in Ukrainian].

7. Chernobryivko M.V., Avramov K.V., Romanenko V.N., Tonkonozhenko A.M., Batutina T.Ya. Sobstvennyie kolebaniya obtekateley raket-nositeley // Visnyk SevNTU: zb. nauk. pr. Vyp. 137/2013. Seriia: Mekhanika, enerhetyka, ekolohiia. - Sevastopol, 2013. S. 15 - 18. [natural vibrations of fairings of rocket-carriers // Visnyk SevNTU: Scientific collected articles, Issue 137/2013. Series: Mechanics, Energy, Ecology. - Sevastopol, 2013. Pp. 15 - 18. - in Russian].

8. [Electronic resource]. - Access mode: https://habr.com/ru/post/410619/].

9. Krivoshapko S.N. K voprosu o primenenii parabolicheskih obolochek vrascheniya v stroitelstve V 2000-2017 godah // Stroitelnaya mehanika inzhenernyih konstruktsiy i sooruzheniy, 2017. - № 4. - S. 4-14. [To the question of the use of parabolic shells of revolution in construction in 2000-2017 // Structural Mechanics of Engineering Structures and Structures, 2017. - No. 4. - Pp. 4-14. - in Russian].

10. Chernobryivko M.V., Avramov K.V. Sobstvennyie kolebaniya parabolicheskih obolochek // Mat. metody ta fiz.-mekh. polia, 2014. - 57, № 3. - S. $78-85$. [Natural vibrations of parabolic shells // Mathematical Methods and Phys-Mech. fields, 2014. - 57, No. 3. - Pp. 78 85. - in Russian].

11. Tornabene F., Viola E. 2-D solution for free vibrations of parabolic shells using generalized diferential quadrature method // European Journal of Mechanics - A/Solids. - 2008. - Vol. 27, № 6. - Pp. 1001-1025.

12. Chen $X$., Ye K. An Exact Dynamic Stiffness Formulation for Predicting Natural Frequencies of Moderately Thick Shells of Revolution // Mathematical Problems in Engineering. - 2018. Vol. 2018.

13. Sahoo $S$. Free vibration behavior of laminated composite stiffened elliptic parabolic shell panel with cutout // Curved and Layered Structures. - 2015. - Vol. 2. - №. 1. - 162-182 p.

14. Chun K.S., Kassegne S.K., Wondimu B.K. Hybrid/mixed assumed stress element for anisotropic laminated elliptical and parabolic shells // Finite Elements in Analysis and Design. - 2009. - Vol. 45. - №. 11. - P. 766-781.

15. Yue H. et al. Modal sensing and control of paraboloidal shell structronic system // Mechanical Systems and Signal Processing. - 2018. - Vol. 100. - P. 647-661.

16. Bazhenov V.A., Krivenko O.P., Solovey M.O. Neliniyne deformuvannya ta stiykist pruzhnih obolonok neodnoridnoyi strukturi. - K.: ZAT «Vipol», 2010. - 316 s. [Nonlinear deformation and stability of elastic shells with inhomogenous structure. Kyiv: CJSC "VIPOL", 316 p. (2010) - in Ukrainian].

17. Bazhenov V.A., Krivenko O.P., Solovey N.A. Nelineynoe deformirovanie i ustoychivost uprugih obolochek neodnorodnoy strukturyi: Modeli, metodyi, algoritmyi, maloizuchennyie i novyie zadachi. - M.: Knizhnyiy dom «LIBROKOM», 2013. - 336 s. [Nonlinear deformation and stability of elastic shells of inhomogeneous structure: Models, methods, algorithms, poorly-studied and new problems. - Moscow: publishing house "LIBROKOM", 336 p. (2013) - in Russian]. 
18. SCAD Office.V.21.System SCAD++ / V.S.Karpilovskyy, E.Z.Kryksunov, A.A Maliarenko, A.V.Perelmuter, M.A.Perelmuter, S.Y. Fialko. - SCAD Soft, Electronic Edition, 2018. - 895 p.

19. Zubchaninov V.G. Osnovy teorii uprugosti i plastichnosti: Uchebn. dlya mashinostroit. spec. vuzov. - M.: Vyssh. shk., 1990. - 368 s. [Fundamentals of the theory of elasticity and plasticity: Textbook. for machine building. specialist. universities. - M .: Higher. school, 1990. -368 p. - in Russian].

Стаття надійшла 28.05.2019

Баженов В.А., Кривенко О.П., Ворона Ю.В.

\section{ВПЛИВ НАГРІВУ НА ВЛАСНІ КОЛИВАННЯ ТОНКИХ ПАРАБОЛІЧНИХ ОБОЛОНОК}

Проведено модальний аналіз параболічних оболонок обертання, що знаходяться в температурному полі. Аналіз проводиться методом, який грунтується на співвідношеннях тривимірної теорії термопружності, скінченно-елементної постановки задачі у приростах та використовує моментну схему скінченних елементів. Для моделювання тонкої пружної оболонки використовується універсальний скінченний елемент. Скінченний елемент побудований на основі просторового ізопараметричного скінченного елемента 3 полілінійними функціями форми для координат і переміщень. Оцінка впливу температурного поля на параметри власних коливань оболонки проводиться у два етапи. На першому етапі за допомогою геометрично нелінійного методу визначається новий напружено-деформований стан конструкції. Далі обчислюються частоти і форми власних коливань оболонки, форма яких збурена дією температурного поля. Проведено детальне дослідження впливу рівномірного і нерівномірного нагріву на власні коливання параболічних оболонок різної висоти. Вивчено коливання параболічних оболонок, що моделюють обтічник ракети. Дослідження показали ефективність застосування розробленого підходу до модального аналізу оболонок.

Ключові слова: вібрації, температурне поле, параболічна оболонка, універсальний просторовий скінченний елемент.

\section{Bazhenov V.A., Krivenko O.P., Vorona Yu.V. \\ EFFECT OF HEATING ON THE NATURAL VIBRATIONS OF THIN PARABOLIC SHELLS}

The modal analysis of parabolic shells of revolution exposed to temperature field is carried out. The analysis is performed according to the method, which is based on the relations of the threedimensional theory of thermoelasticity, a finite-element formulation of the problem in increments and uses the finite element moment scheme. A universal finite element is used to model a thin elastic shell. The finite element is based on an isoparametric solid finite element with polylinear shape functions for coordinate and displacement interpolation. Evaluation of the effect of the temperature field on the parameters of the natural vibrations of the shell is performed according to the developed method in two stages. The new stress-strain state of the structure, caused by the applied temperature field, is determined using a geometrically non-linear approach. Further, the frequencies and modes of the natural vibrations of the shell whose shape is perturbed by the action of the temperature field are calculated. The effect of uniform and non-uniform heating on the natural vibrations of parabolic shells of revolution with various heights is investigated. The vibrations of the parabolic shells modelling rocket fairings are studied. The phenomenon of aerodynamic heating of a parabolic shell (head fairing) may occur at the initial stage of entry of the carrier rocket into the atmosphere. This can lead to significant heating of the fairing surface. At the same time the shell is non-uniformly heated through the height. The considered parabolic shells are essentially deep and rather rigid. Therefore, the effect of heating on the characteristics of natural vibrations is insignificant. It has been found that shallow shells have lower frequencies and significantly different modes of natural vibration. Presented studies have shown the effectiveness of the application of the developed approach to the modal analysis of the shells.

Keywords: vibrations, temperature filed, parabolic shell, universal solid finite element. 
Баженов В.А., Кривенко О.П., Ворона Ю.В.

\section{ВЛИЯНИЕ НАГРЕВА НА СОБСТВЕННЫЕ КОЛЕБАНИЯ ТОНКИХ ПАРАБОЛИЧЕСКИХ ОБОЛОЧЕК}

Выполнен модальный анализ параболических оболочек вращения, находящихся в температурном поле. Анализ проводится методом, основанном на соотношениях трехмерной теории термоупругости, конечно-элементной постановки задачи в приращениях и использует моментную схему конечных элементов. Для моделирования тонкой упругой оболочки используется универсальный конечный элемент. Конечный элемент построен на основе пространственного изопараметрического конечного элемента с полилинейнымы функциями формы для координат и перемещений. Оценка влияния температурного поля на параметры собственных колебаний оболочки проводится в два этапа. На первом этапе с помощью геометрически нелинейного метода определяется новое напряженно-деформированное состояние конструкции. Далее вычисляются частоты и формы собственных колебаний оболочки, форма которых возмущена действием температурного поля. Проведено детальное исследование влияния равномерного и неравномерного нагрева на собственные колебания параболических оболочек различной высоты. Изучены колебания параболических оболочек, моделирующих обтекатель ракеты. Исследования показали эффективность применения разработанного подхода к модального анализа оболочек.

Ключевые слова: вибрации, температурное поле, параболическая оболочка, универсальный пространственный конечный элемент.

\section{УДК 539.3}

Баженов В.А., Кривенко О.П., Ворона Ю.В. Вплив нагріву на власні коливання тонких параболічних оболонок // Опір матеріалів і теорія споруд: наук.-тех. збірн. - К.: КНУБА, 2019. - Вип. 103. - С. 3-16. - Англ.

Розглядається вплив нагріву на параметри власних коливань параболічних оболонок обертання.

Табл. 6. Іл. 10. Бібліогр. 20 назв.

\section{UDC 539.3}

Bazhenov V.A., Krivenko O.P., Vorona Yu.V. Effect of heating on the natural vibrations of thin parabolic shells // Strength of Materials and Theory of Structures: Scientific-and-technical collected articles. - K.: KNUCA, 2019. - Issue 103. - P. 3-16.

The effect of heating on the parameters of natural vibrations of parabolic shells of revolution is considered.

Table 6. Fig. 10. Ref. 20.

\section{УДК 539.3}

Баженов В.А., Кривенко О.П., Ворона Ю.В. Влияние нагрева на собственные колебания тонких параболических оболочек // Опір матеріалів і теорія споруд: наук.-тех. збірн. - К.: КНУБА, 2019. - Вип. 103. - С. 3-16. - Англ.

Рассматривается влияние нагрева на параметры собственных колебаний параболических оболочек вращения.

Табл. 6. Іл. 10. Библиогр. 20 назв. 
Автор (вчена ступень, вчене звання, посада): доктор технічних наук, професор, академік Національної академії педагогічних наук України, директор НДІ будівельної механіки БАЖЕНОВ Віктор Андрійович

Адреса робоча: 03680 Украӥна, м. Київ, Повітрофлотський проспект 31, Київський національний університет будівництва і архітектури.

Робочий тел.: +38(044) 245-48-29.

мобільний тел.: +38(067)111-22-33

Імейл: bazhenov.va@knuba.edu.ua

ORCID ID: https//orcid/org/0000-0002-5802-9848

Автор (вчена ступень, вчене звання, посада): кандидат технічних наук, стариий науковий співробітник, провідний науковий співробітник НДІ будівельної механіки КНУБА КРИВЕНКО Ольга Петрівна

Адреса робоча: 03680 Украӥна, м. Київ, Повітрофлотський проспект 31, Київський національний університет будівництва і архітектури.

Робочий тел.: +38(044) 245-48-29.

мобільний тел.: +38(066) 048-32-77

Імейл: kryvenko.op $@$ knuba.edu.ua

ORCID ID: https//orcid/org/0000-0002-1623-9679

Автор (вчена ступень, вчене звання, посада): кандидат технічних наук, доцент, професор кафедри будівельної механіки ВОРОНА Юрій Володимирович

Адреса робоча: 03680 Украӥна, м. Київ, Повітрофлотський проспект 31, Київський національний університет будівництва і архітектури.

Робочий тел.: +38(044) 245-48-29.

мобільний тел.: $+38(050) 750-13-61$

Імейл: vorona.iuv@knuba.edu.ua

ORCID ID: https//orcid/org/0000-0001-8130-7204 